\title{
SISTEM PEWARISAN KEKERABATAN PARENTAL \\ DALAM HUKUM ADAT SUKU BUGIS
}

\author{
Muhammad Syaiful \\ Fakultas Hukum Institut Ilmu Sosial Dan Bisnis Andi Sapada \\ Email: muhammadsyaiful0311@gmail.com
}

\begin{abstract}
Abstrak
Suku Bugis adalah salah satu etnik di Indonesia yang sebagian besar masyarakatnya berada di Provinsi Sulawesi Selatan yang mendiami beberapa wilayah seperti Kabupaten Wajo, Bone, Luwu, Soppeng, Sidrap, Pinrang, Parepare, Barru. Akan tetapi karena adanya pernikahan menyebabkan adanya pertalian darah dengan Makassar dan Mandar. Daerah peralihan antara Bugis dengan Makassar adalah Maros, Pangkep, Sinjai, Bulukumba. Dan peralihan antara Bugis dengan Mandar ialah Polman serta Pinrang. Di dalam masyarakat suku Bugis menganut sistem pewarisan kekerabatan Parental yakni menarik garis keturunan dari kedua belah pihak orang tua, baik dari garis bapak maupun ibu.
\end{abstract}

\section{PENDAHULUAN}

Hukum adat ialah suatu kebiasaan yang berkembang di dalam masyarakat dan kemudian menjadi suatu hukum yang harus dipatuhi oleh segenap anggota masyarakat. Sedangkan hukum waris adat adalah hukum yang mengatur sistem hukum dan asas-asas tentang harta warisan, pewaris dan ahli waris beserta cara pengalihannya yang digunakan oleh suku-suku bangsa atau etnik yang hidup di wilayah Indonesia. Adapun yang termasuk dalam harta warisan adat diantaranya harta pusaka, harta perkawinan, harta bawaan dan harta pembagian. 
Sistem pewarisan yang dianut dalam masyarakat suku Bugis ialah sistem kekerabatan Parental, yakni yang menganut sistem kekeluargaan dengan menarik garis keturunan dari kedua belah pihak orang tua yaitu baik dari garis bapak maupun garis ibu. Sistem pewarisan kekerabatan Parental ini memiliki ciri khas tersendiri, bahwa yang merupakan ahli waris ialah anak laki-laki maupun anak perempuan. Mereka mempunyai hak yang sama atas harta peninggalan atau warisan orangtuanya sehingga dalam proses pengalihan sejumlah harta kekayaan dari pewaris ke ahli waris, anak laki-laki dan anak perempuan mempunyai hak untuk diperlakukan sama.

\section{PEMBAHASAN}

Masyarakat suku Bugis merupakan suatu kelompok masyarakat yang sebagian besar bermukim di Provinsi Sulawesi Selatan akan tetapi seiring waktu saat ini telah banyak tersebar di daerah-daerah wilayah Negara Kesatuan Republik Indonesia.

Di salah satu daerah yang berada di Provinsi Sulawesi Tenggara yaitu Kabupaten Kolaka Timur tepatnya di Desa Aladadio Kecamatan Aere telah banyak bermukim masyarakat adat Suku Bugis Bone, yang salah satunya disebabkan oleh adanya dorongan atau ajakan dari sanak saudara yang terlebih dahulu berada di daerah ini.

Adat dan budaya suku Bugis Bone masih terpelihara dengan baik oleh masyarakat suku Bugis Bone yang berada di Desa Aladadio Kecamatan Aere Kabupaten Kolaka Timur, hal ini dapat dilihat dari budaya gotong royong, pelepasan ayam (Malippessang Manu), pelemparan beras pada proses pernikahan (Marem'pe Berre) dan pembagian harta warisan (Dibageni Harta Warisangge). Sedangkan berbicara tentang pembagian harta warisan menurut adat suku Bugis Bone di Desa Aladadio Kecamatan Aere Kabupaten Kolaka Timur terdapat hal yang unik untuk dikaji lebih dalam lagi, hal ini dapat dilihat dari proses pembagian harta warisan yang akan dibagikan kepada seluruh ahli waris diberikan wewenang sepenuhnya kepada anak tertua untuk membagi harta warisan. Jika ada kepala keluarga yang telah meninggal dunia hak dari kepala keluarga tersebut diberikan kepada anak tertua 
untuk membagikan harta warisan yang ditinggalkan, hal ini dilakukan karena masyarakat setempat percaya jika anak tertua bisa membagikan harta warisan tersebut dengan adil tanpa ada pertikaian dengan ahli waris lainnya. (Jumardin dan Sitti Halimang, 2021: 5-6)

Di salah satu daerah di Provinsi Riau yang merupakan wilayah Kesatuan Negara Republik Indonesia tepatnya di Kecamatan Enok Kabupaten Indragiri Hilir banyak berdiam masyarakat suku Bugis yang memiliki adat istiadat dan hukum adat yang merupakan warisan dari nenek moyang dan berlaku secara turun-temurun dari generasi ke generasi. Pada masyarakat Bugis di Kecamatan Enok yang pertama berkedudukan sebagai ahli waris adalah anak laki-laki dan anak perempuan serta keturunannya (cucu-cucunya). Anak kandung memiliki kedudukan yang terpenting di dalam setiap masyarakat adat dan anak yang masih didalam kandungan seorang ibu juga menjadi ahli waris, asalkan sewaktu anak itu lahir dalam keadaan hidup. Begitupula terhadap anak yang lahir hidup dari ibunya yang sedang mengandung ketika ayah kandungnya wafat, ia berhak menjadi ahli waris dari ayahnya. (Deo Andika Putra Sihombing, 2016: 3-5)

\section{KESIMPULAN}

Sistem pewarisan kekerabatan Parental yang dianut oleh masyarakat adat suku Bugis menempatkan kedudukan anak laki-laki dan perempuan sama atau sejajar. Dan kemungkinan terjadinya perselisihan mengenai besarnya pembagian warisan sangat besar terjadi dikarenakan besar harta warisan yang didapatkan baik anak laki-laki dan anak perempuan setara jumlahnya. Dan dibeberapa kasus, banyak yang memilih sistem pembagian kewarisan secara Islam karena dalam Islam anak laki-laki mendapat warisan semestinya lebih banyak dibandingkan anak perempuan. 


\section{DAFTAR PUSTAKA}

Jumardin dan Sitti Halimang, Pembagian Harta Warisan Pada Masyarakat Adat Bugis Bone di Desa Aladadio Kecamatan Aere Kabupaten Kolaka Timur, Kendari: Jurnal Institut Agama Islam Negeri Kendari, 2021.

Deo Andika Putra Sihombing, Pembagian Waris Adat Masyarakat Suku Bugis di Kecamatan Enok, Kabupaten Indragiri Hilir, Provinsi Riau, Medan: Jurnal Universitas Sumatera Utara, 2016.

\section{Sumber dari internet:}

https://id.wikipedia.org/wiki/Suku Bugis

https://ejournal.iainkendari.ac.id/index.php/fawaid/article/download/3084/1570

https://repositori.usu.ac.id/handle/123456789/470 